\title{
COSMIDS AND TRANSCRIBED SEQUENCES FROM CHROMOSOME 11q23
}

\author{
Motonobu Katoh, Yuzuki Nakagawa, * Toshio Yawata, \\ Satoshi Kumano, Eisuke Kobayashi, Akihiro Kurimasa, \\ Hiroyuki Kugor, and Mitsuo OshImURA** \\ Department of Molecular and Cell Genetics, School of Life Sciences, \\ Faculty of Medicine, Tottori University, \\ 86 Nishimachi, Yonago, Tottori 683, Japan
}

\begin{abstract}
Summary To obtain cosmid markers and transcribed sequences from a specific chromosome region, a series of radiation-reduced hybrids (RHs) containing various regions of human chromosome 11 was prepared from microcell hybrid A9 (neo11) cells containing a normal human chromosome 11 tagged with pSV2neo at $11 \mathrm{p} 11.2$. Among 15 radiation hybrid clones isolated, $\mathrm{RH}(11)-9$ which contains a q23 fragment in addition to the neo integration site, was used for the construction of a cosmid library. Cosmid clones having human DNA sequences were screened, and localized by Southern hybridization with the radiation hybrid panel. Fif cosmids were assigned to $11 \mathrm{q} 23$ and 6 cosmids to $11 \mathrm{p} 11.2$. Exon amplification proceeded with 23 of the 59 cosmids and 16 putative exons were cloned. Three of them were identical to those constituting a known gene which locates on q23 (ATDC), and the others were unknown. Thus, the RHs containing various subchromosomal fragments of chromosome 11 were useful for constructing region-specific DNA markers. The RH(11)-9 cells and putative exons also facilitate the positional cloning of genes in the $11 \mathrm{q} 23$ region.
\end{abstract}

Key Words chromosome 11q23, radiation-reduced hybrid, cosmids, exon amplification, transcribed sequences

\section{INTRODUCTION}

The $11 \mathrm{q} 23$ region reportedly harbors the genes responsible for hereditary dis-

Received May 18, 1995; Revised version accepted August 16, 1995.

* Present address: Hatano Research Institute/Food and Drug Safety Center, 729-5 Ochiai, Hadano, Kanagawa 257, Japan.

** To whom correspondence should be addressed. 
orders such as Ataxia-telangiectasia (Gatti, 1991; Sobel et al., 1992) and paraganglioma, which is potentially related to genomic imprinting (Heutink et al., 1992; Devilee et al., 1994). Chromosome deletions and/or allelic losses on 11q22-q24 have been found in breast, ovalian, colorectal, and cervical carcinomas and malignant melanomas (Keldysh et al., 1993; Tomlinson et al., 1993; Foulkes et al., 1993; Hampton et al., 1994; Carter et al., 1994). Three genes whose defect by chromosome translocations cause some leukemias, have been identified (Ziemin et al., 1991; Akao et al., 1992; Chen et al., 1993; reviewed by Rabbits, 1994). Chromosome deletions or translocations on $q 23$ possibly distinct from that including the three genes have been found in leukemias (Cherif et al., 1992; Kobayashi et al., 1993). Thus, the accumulation of cosmid clones and transcribed sequences from this region will facilitate the cloning of genes related to the disorders described above and to construct a transcriptional map of this defined region.

To clone human genes and to construct a human genome map by means of the positional approach, human DNA segments must be isolated from a specific human chromosome or chromosomal region. Interspecies somatic cell hybrids containing a single human chromosome have been used as a donor of human chromosome specific DNA (Emi et al., 1992; Hori et al., 1992; Kugoh et al., 1995). An irradiation and fusion procedure has reduced the size of human chromosomes in hybrid cells (Leach et al., 1989; Tamari et al., 1992; Gerhard et al., 1992). This allows DNAs to be more efficiently isolated from a specific region by PCR, utilizing interspersed repetitive sequences (Zoghbi et al., 1991; Gillet et al., 1993). The cloned DNA segments using PCR are however, relatively short, therefore subsequent screening of genome library is inevitable to analyze genome structure of chromosome region in interest.

In this study, we generated radiation-reduced hybrids ( $\mathrm{RHs}$ ) containing various regions of chromosome 11 , including the 11 q23 region, constructed a cosmid library from this region and selected transcribed sequences by exon amplification (Buckler et al., 1991). These should be valuable resources for the genome and transcribed mapping of chromosome 11 .

\section{MATERIALS AND METHODS}

Generation of radiation-reduced hybrids. A9(neo11) is a mouse A9 cell hybrid containing a single human chromosome 11, upon which the selectable marker pSV2neo is integrated at p11.2 (Koi et al., 1989). Cells were maintained in Dulbecco's modified Eagle's medium (DMEM) supplemented with $10 \%$ calf serum, $100 \mathrm{units} / \mathrm{ml}$ penicillin and $100 \mu \mathrm{l} / \mathrm{ml}$ streptomycin. The antibiotic G418 sulfate (Gibco) at $800 \mu \mathrm{g} / \mathrm{ml}$ was added to the growth media. A9(neo11) cells were irradiated using a cobalt source set at $100 \mathrm{rad} / \mathrm{sec}$ for periods calculated to deliver radiation doses of 2,000 and 3,000 rads, and fused with A9 cells. Irradiation and fusion were performed following the described protocol (Tamari et al., 1992) and 
G418-resistant colonies were cloned and expanded for subsequent analyses.

Inter-Alu PCR. High molecular weight genomic DNAs were prepared by proteinase $\mathrm{K}$ digestion and phenol/chloroform extraction. Genomic DNA (20 ng) from RH cells were used in inter-Alu PCR amplification using the primer 559 (Ledbetter et al., 1990) following the described protocol (Kurimasa et al., 1994). Products were visualized by staining with ethidium bromide after electrophoresis in $0.8 \%$ agarose gels.

Southern blot analysis of RHs. High molecular-weight DNAs extracted from RHs were digested with EcoRI for Southern blotting, which was performed using the following 27 chromosome 11-specific markers (Tokino et al., 1991; Hori et al., 1992) and pSV2neo; D11S483, D11S459, cCI11-546, cCI11-489, D11S431, cCI11-421, D11S466, cCI11-370, D11S455, cCI11-382, D11S441, cCI11-393, cCI11496, D11S436, D11S427, D11S426, D11S429, cCI11-362, cCI11-279, D11S464, D11S448, D11S428, D11S456, D11S473, D11S425, cCI11-276, and D11S439. The loci whose symbol names have not yet been defined are designated by the probe names in the text (Hori et al., 1992).

FISH analyses. The FISH procedure was as described (Takahashi et al., 1990, 1992; Kugoh et al., 1995). Total human DNA was used as the probe for FISH painting. FISH for cosmid mapping was carried out using normal human lymphocytes.

Cosmid library construction and mapping. A cosmid library was constructed from the genomic DNA of the radiation-reduced hybrid cell line, RH(11)-9, as described (Tokino et al., 1991), using the cosmid vector pWEX15. Clones carrying human DNA inserts were selected by plaque hybridization with the total human DNA as a probe, then by Southern hybridization with total human and mouse DNAs. The human DNA clones were mapped by Southern hybridization with the radiation hybrid panel.

Exon amplification. Exon amplification was performed using cosmids as described (Buckler et al., 1991). Briefly, cosmids were completely restriction-digested by $B a m H I / B g / I I$ and ligated to the splicing vector pSPLI at the BamHI site. Constructs were transfected into Cos 7 cells by the electroporation (Bio-Rad, Gene pulser; $1.2 \mathrm{kV}, 25 \mu \mathrm{F}$ ). Cytoplasmic RNAs were recovered $48 \mathrm{hr}$ after transfection and reverse transcribed followed by two steps of amplification using the primers $\mathrm{SD} 2 / \mathrm{SA} 2$ and SD1/SA1. Second PCR products were cloned into the BamHI/SalI site of plasmid vector pBluescript SK(-).

Analysis of cloned exon candidates.

Preparation of probes for Southern/Northern hybridization: Cloned PCR products were excised by restriction digestion with $B a m \mathrm{HI} / \mathrm{SalI}$, and isolated by agarose gel electrophoresis. Isolated sequences ${ }^{32} \mathrm{P}-\mathrm{labeled}$ by means of random priming, were used as probes for Southern/Northern blot analyses.

Southern blot analysis: Cosmid clones were restriction-digested with $\mathrm{BamHI}$ $B g l I I$, and Southern blots were prepared. Genomic DNAs were isolated from 
human lymphocytes and calf, rat, mouse, and guinea pig tissues. Twenty micrograms of each sample was digested with $E c o$ RI and Southern blots were prepared. Prehybridization and hybridization were performed overnight at $65^{\circ} \mathrm{C}$ in solution containing $10 \%$ SDS, $7 \%$ polyethylene glycol 8000 , and $200 \mu \mathrm{g} / \mathrm{ml}$ human placental DNA. ${ }^{32}$ P-labeled probes described above were used in hybridization. After hybridization, filters were washed at $65^{\circ} \mathrm{C}$ with $0.1 \times \mathrm{SSC}$ and $0.1 \% \mathrm{SDS}$ and exposed for autoradiography to X-ray films at $-70^{\circ} \mathrm{C}$.

Northern blot analysis: Total RNA was extracted from rat tissues by the AGPC method (Chomczynski and Sacchi, 1987). RNA samples (20 $\mu \mathrm{g})$ were then resolved by electrophoresis in a $1 \%$ agarose, $6 \%$ formamide gel and blotted onto Nylon membranes (Amersham). These were prehybridized and hybridized in $50 \%$ formamide, $0.5 \% \mathrm{SDS}, 5 \times \mathrm{SSPE}, 100 \mu \mathrm{g} / \mathrm{ml}$ shared denatured salmon sperm DNA. ${ }^{32}$ p-labeled probes described above were used in hybridizations. After overnight hybridization at $42^{\circ} \mathrm{C}$, the membranes were washed with $0.1 \times \mathrm{SSC}, 0.1 \%$ SDS at $50^{\circ} \mathrm{C}$.

Sequencing and sequence analysis: Sequences were demonstrated by means of dideoxy chain termination method (Sanger et al., 1977), using the BcaBEST sequencing kit (TAKARA). Sequences were analyzed using the FASTA network service of DDBJ.

\section{RESULTS AND DISCUSSION}

Sixty radiation-reduced hybrids (RHs) were constructed from A9(neo11) cells, and the human DNA content in them were estimated by the banding patterns using inter-Alu PCR (data not shown). Of these, $15 \mathrm{RHs}$ containing various amounts of human DNA were selected, and the retained chromosome regions were determined by Southern blotting with 28 DNA markers on chromosome 11. An RH panel consisting of 15 hybrids was prepared to localize the DNA sequences to 20 regions on chromosome 11 (Fig. 1). Among $15 \mathrm{RHs,} \mathrm{RH(11)-9} \mathrm{retained} \mathrm{11q23}$ in addition to $\mathrm{p} 11.2$, in which the selection marker pSV2neo has been integrated. FISH analysis (painting) using total human DNA was performed to investigate the integrity of the q23 and neo-tagged fragments in $\mathrm{RH}(11)-9$ (Fig. 2A). A human chromosome fragment was inserted into the mouse chromosome in most of the metaphase plates analyzed. Thus, human chromosome fragments including the $11 \mathrm{q} 23$ and neo-tagged regions were stably retained as an insertion into mouse chromosomes.

A cosmid library was constructed from the RH(11)-9. Cosmid clones carrying human DNA were screened by plaque hybridization with total human DNA and subsequent Southern blot hybridization with total human and mouse DNA probes. Ninety-seven selected clones were hybridized to the RH panel to localize on the chromosome 11 (data not shown). Of these, $59(60 \%)$ were localized on 3 regions in 11q23, represented by the cosmid markers D11S428(cCI11-6), DI1S425(cCI11-1), 


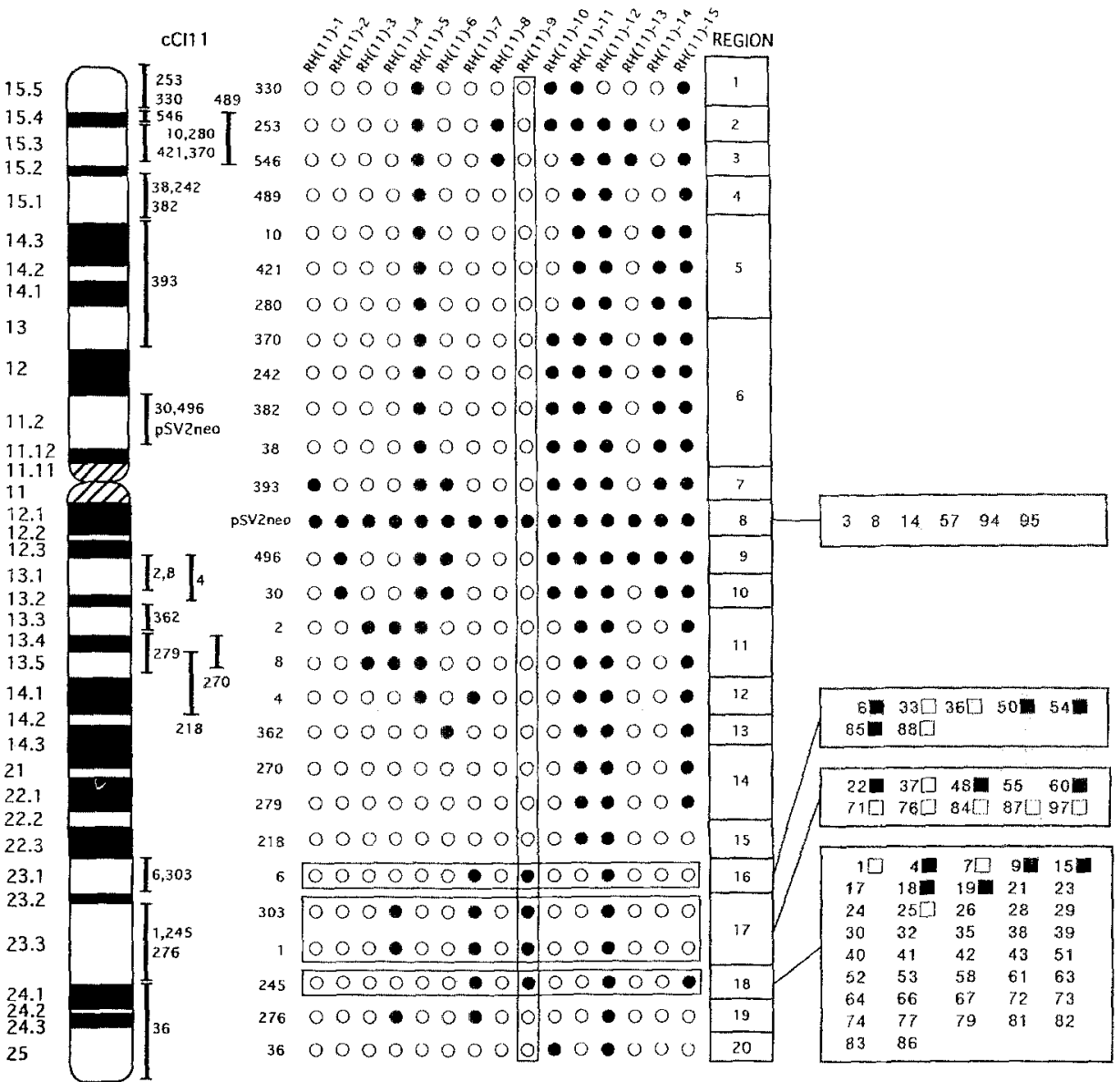

Fig. 1. An ideogram of human chromosome 11 (left) and a summary of the results of Southern blot hybridization showing the presence (solid circle) or absence (open circle) of specific DNA sequences on human chromosome 11 (cosmid marker cCI1ls; Tokino et al, 1991) in radiation-reduced hybrids. Only the numbers of cosmid markers are shown. The numbers of cloned cosmids (cYS11s) located on $11 \mathrm{q} 23$ and $\mathrm{p} 11.2$ are represented on the right. The square following the number indicates identification (solid) or lack (open) of putative exons.

and D11S456(cCI11-245). Six were localized on $11 \mathrm{pl} 1.2$ represented by the integrated pSV2neo (Fig. 1). Three selected cosmids (cYS11-4, 6, 9) were confirmed their map positions on $11 \mathrm{q} 23$ by FISH analyses (Fig. 2B). The remaining 32 were not localized using the RH panel. An alternative study such as FISH is required to localize these clones. We noted that 6 (cYS11-29, 35, 36, 54, 82, 83) of the 59 cosmids mapped on 11q23 cross-hybridized to mouse DNA under highly stringent conditions. Whether these cosmids are chimeras of human/mouse DNA or con- 


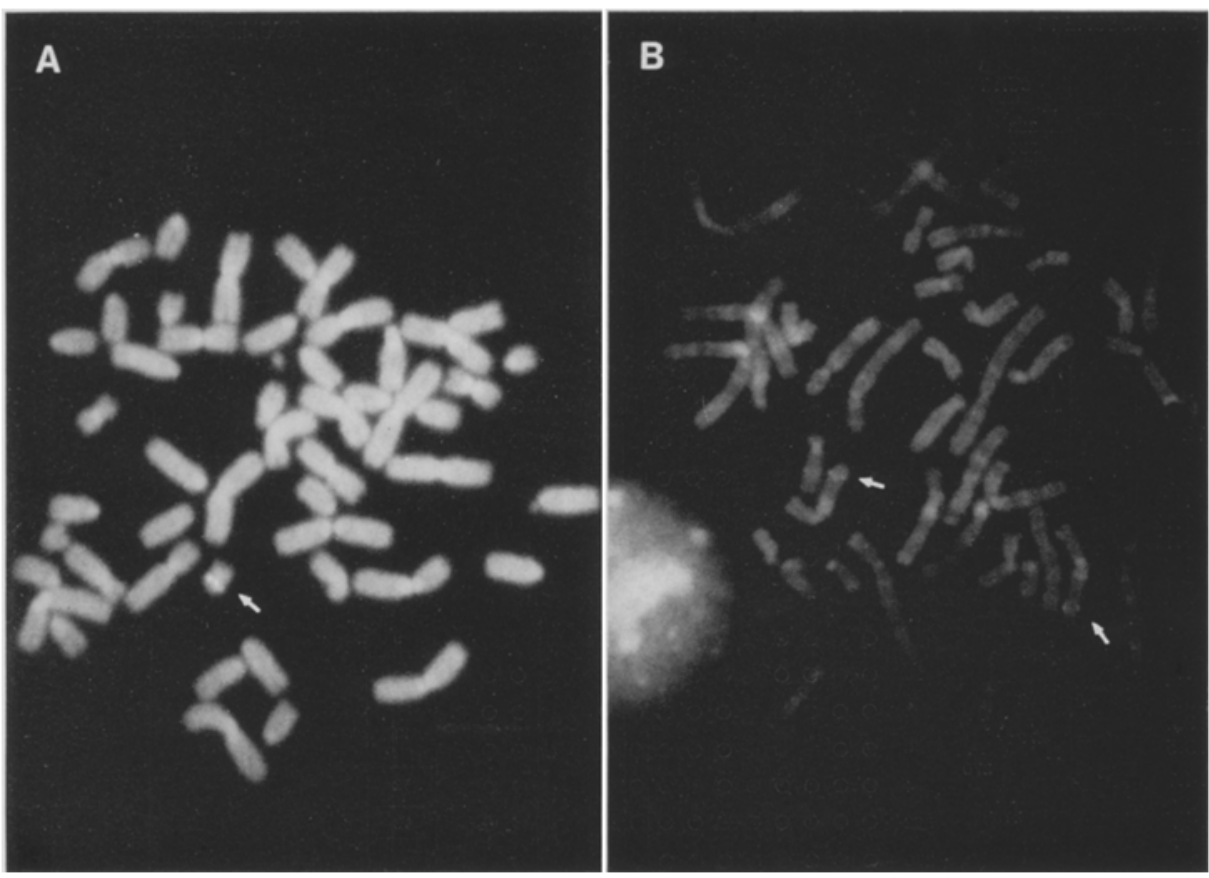

Fig. 2. A : A metaphase spread of $\mathrm{RH}(11)-9$ after in situ hybridization with total human DNA. The arrow indicates a human chromosome fragment inserted into a mouse chromosome. B: Mapping of cosmid cYS11-6 on chromosome 11. Arrows indicate the specific hybridization signals of twin spots on $11 \mathrm{q} 23$.

taining conserved sequences throughout species, remains to be investigated.

Exon amplifications were performed using the 23 cosmids localized on 11q23, to isolate region-specific transcribed sequences. First PCR products using the primer set SD2/SA2 were recovered from agarose gels as fractions from 400 to 1,400 bp. Second PCR products using the primer set SD1/SAl corresponding to the major PAGE bands were independently recovered and cloned into the plasmid vector. As a first screening, cloned DNAs corresponding to the major bands on PAGE were selected and their origin was ascertained by Southern hybridization with cosmids. Sixteen clones were derived from the original cosmids. The following analyses were performed using the 16 exon candidates. Searching for cross-species sequence conservation has been adopted as an approach to identifying a gene in a stretch of genomic DNA (Monaco et al., 1986; Page et al., 1987; Rommens et al., 1989; Call et al., 1990). To characterize the cloned exon candidates, we first performed Southern blot analysis using genomic DNA derived from selected mammals (Fig. 3). Eleven clones were conserved throughout human, calf, mouse, rat, and guinea pig samples, whereas the other 5 clones were single copy in the human genome. This may be due to the relatively stringent hybridization conditions. 


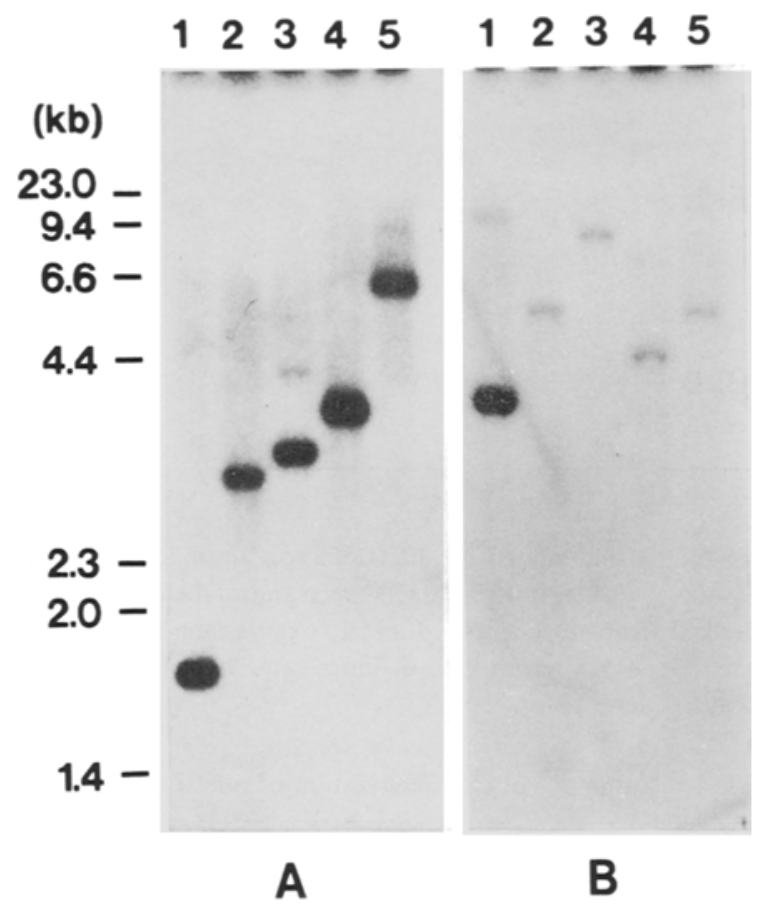

Fig. 3. Southern blots of cloned products of exon amplification. 4A-3 (A) and 15B-18 (B) were excised, gel purified, radiolabeled and hybridized to DNA samples from various species. Lane 1, human; lane 2, calf; lane 3, rat; lane 4, mouse; lane 5 , guinea pig.

The transcription of the eleven conserved sequences were subsequently investigated by Northern blotting using total RNAs derived from rat tissues (Fig. 4). Of these, 6 clones detected transcripts in rat tissues. The probes used for hybridization experiments included the common 93 bp sequences of the HIV tat exon derived from splicing vector. The additional sequences did not significantly influence the experiments. For the other 5 clones which did not detect transcripts by Northern blotting using total RNA, more sensitive studies, such as RT-PCR are required to ascertain whether or not they are actually transcribed.

To characterize 16 exon candidates, we also performed sequence analyses. All the exon candidates had the correct splicing junction with the $5^{\prime}$ and $3^{\prime}$ splice sites and were flanked on both sides by the tat sequences. A homology search with the FASTA program revealed that 3 clones $60 \mathrm{D}-1,54 \mathrm{~B}-1$, and $54 \mathrm{D}-1$ were identical to exons 5,5\&6, and 7, constituting a human cDNA ATDC, which is localized on $11 \mathrm{q} 23$ and partially complements the radiosensitivity of fibroblasts from a patient with Ataxia-telangiectasia group D (Kapp et al., 1992; Leonhardt et al., 1994). The other sequences did not show significant similarities to known genes at both the nucleic acid and amino acid level. 


\section{$\begin{array}{llllllllll}1 & 2 & 3 & 4 & 5 & 6 & 7 & 8 & 9 & 10\end{array}$}

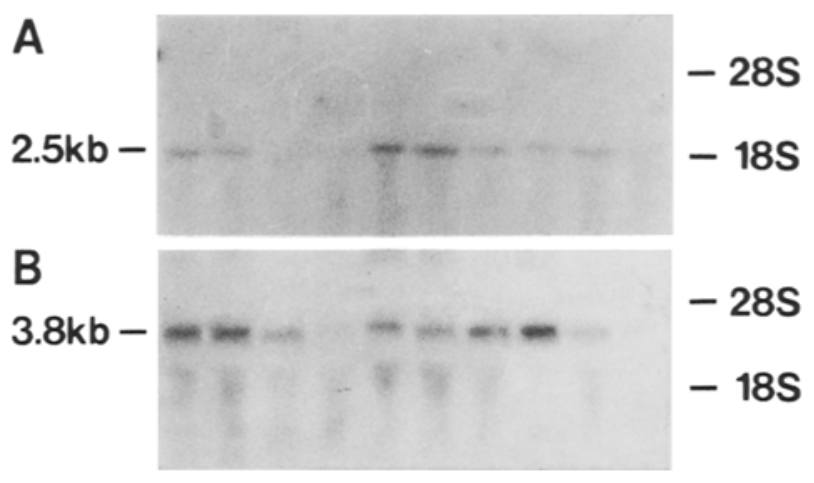

Fig. 4. Northern blots using cloned products of exon amplification. Gel purified inserts of clones $4 \mathrm{~A}-3$ (A) and $15 \mathrm{~B}-18$ (B) were radiolabeled and hybridized to total RNA derived from rat tissues. Lane 1, ovary; lane 2, brain; lane 3, liver; lane 4 , stomach; lane 5 , uterus; lane 6 , lung; lane 7 , heart; lane 8 , skeletal muscle; lane 9 , kidney; lane 10 , spleen.

Table 1. Summary of characterization of putative exon clones.

\begin{tabular}{ccccc}
\hline Clone name & $\begin{array}{c}\text { Fragment } \\
\text { length } \\
(\mathrm{bp})\end{array}$ & $\begin{array}{c}\text { Zoo } \\
\text { Southern }\end{array}$ & Northern & $\begin{array}{c}\text { Sequence } \\
\text { homology }\end{array}$ \\
\hline $4 \mathrm{~A}-3$ & 98 & $\mathrm{C}$ & + & - \\
$9 \mathrm{~A}-5$ & 68 & $\mathrm{C}$ & - & - \\
$15 \mathrm{~B}-18$ & 118 & $\mathrm{C}$ & + & - \\
$18 \mathrm{~A}-13$ & 135 & $\mathrm{~S}$ & N.T. & - \\
$19 \mathrm{C}-1$ & 139 & $\mathrm{~S}$ & N.T. & - \\
$19 \mathrm{D}-1$ & 53 & $\mathrm{C}$ & + & - \\
$22 \mathrm{C}-1$ & 134 & $\mathrm{~S}$ & N.T. & - \\
$22 \mathrm{D}-1$ & 150 & $\mathrm{~S}$ & N.T. & - \\
$48 \mathrm{D}-1$ & 149 & $\mathrm{C}$ & - & - \\
$60 \mathrm{D}-1$ & 104 & $\mathrm{C}$ & + & ATDC exon 5 \\
$6 \mathrm{~A}-1$ & 61 & $\mathrm{C}$ & - & - \\
$6 \mathrm{D}-1$ & 123 & $\mathrm{~S}$ & N.T. & - \\
$50 \mathrm{D}-3$ & 124 & $\mathrm{C}$ & - & - \\
$54 \mathrm{~B}-1$ & 195 & $\mathrm{C}$ & + & ATDC exon5+6 \\
$54 \mathrm{D}-1$ & 99 & $\mathrm{C}$ & + & ATDC exon 7 \\
$85 \mathrm{D}-2$ & 101 & $\mathrm{C}$ & - & - \\
\hline
\end{tabular}

The results of Southern and Northern blot analyses are presented. C, conserved; S, single copy in human genome; N.T., not tested. The similarity of DNA and predicted amino acid sequences with DNA and protein databases was assesed by means of FASTA. The sequences have been deposited in DDBJ (accession numbers D63746 through D63758). 
We selected transcribed sequences from restricted regions of a human chromosome, to help construction of a transcriptional map. Each step in reducing part of the genomic DNA from an intact chromosome 11 to exon candidate sequences, has generated valuable materials for the genome analysis. This includes an RH panel for mapping cloned DNA probes on chromosome 11, q23 region specific cosmid clones as genome DNA resources for positional cloning of genes related to diseases and exon sequences for screening cDNAs from q23. Once a cDNA is cloned, the gene structure can be efficiently analyzed using the original cosmid.

Reduction of the human chromosome fragment in hybrid cell increased regional specificity but decreased the fraction of cloned human DNA in the cosmid library. Since we wished to screen human DNA clone from a hybrid cosmid library, we overcome this problem by stepwise hybridization, which is laborious but simple. The cloned DNA segment described here has not been ordered on the basis of a physical map. Integration of the resources into physical maps will facilitate the construction of a region specific transcriptional map of $11 \mathrm{q} 23$.

Acknowledgments We thank the Japanese Cancer Research Resources Bank for providing some DNA probes. This work was supported in part by the Special Coordination Funds Promoting for Science and Technology, Science and Technology Agency, Japan.

\section{REFERENCES}

Akao Y, Seto M, Yamamoto K, Lida S, Nakazawa S, Inazawa J, Abe T, Takahashi T, Ueda $\mathbf{R}$ (1992): The RCK gene associated with $t(11 ; 14)$ translocation is distinct from the MLL/ALL-1 gene with $\mathrm{t}(4 ; 11)$ and $\mathrm{t}(11 ; 19)$ translocation. Cancer Res 52:6083-6087

Buckler AJ, Chang DD, Graw SL, Brook D, Haber DA, Sharp PA, Housman DE (1991): Exon amplification: a strategy to isolate mammalian genes based on RNA splicing. Proc Natl Acad Sci USA 88: 4005-4009

Call KM, Glaser T, Ito CY, Buckler AJ, Pelletier J, Haber DA, Rose EA, Kral A, Yeger H, Lewis WH, Jones C, Housman DE (1990): Isolation and characterization of a zinc finger polypeptide gene at the human chromosome 11 Wilms' tumor locus. Cell 60: 509-520

Carter SL, Negrini M, Baffa R, Gillum DR, Rosenberg AL, Schwartz GF, Croce CM (1994): Loss of heterozygosity at 11q22-q23 in breast cancer. Cancer Res 54: 6270-6274

Chen Z, Brand NJ, Chen A, Chen S-J, Tong J-H, Wang Z-Y, Waxman S, Zelent A (1993): Fusion between a novel Kruppel-like zine finger gene and retinoic acid receptor-a locus due to a variant $\mathrm{t}(11: 17)$ translocation associated with acute promyelocytic leukemia. EMBO J 12: $1161-$ 1167

Cherif D, Der-Sarkissan H, Derre J, Tokino T, Nakamura Y, Berger R (1992): The 11q23 breakpoint in acute leukemia with $t(11 ; 19)(q 23 ; p / 3)$ is distal to those of $t(4 ; 11), t(6 ; 11)$ and $t(9 ; 11)$. Genes Chromosomes Cancer 4: 107-112

Chomczynski P, Sacchi N (1987): Single-step method of RNA isolation by acid guanidium thiocyanate-phenol-chloroform extraction. Anal Biochem 162: 156-159

Devilee P, Van Schothorst EM, Bardoel AFJ, Bonsing B, Kuipers-Dijkshoorn N, James MR, Freuren G, Van der may AGL, Cornelisse CJ (1994): Allelotype of head and neck paragangliomas: allelic imbarance is confined to the long arm of chromosome 11 , the site of the predisposing locus PGL. Genes Chromosomes Cancer 11: 71-78

Emi M, Takahashi E, Koyama K, Okui K, Oshimura M, Nakamura Y (1992): Isolation and mapping of 88 new RFLP markers on human chromosome 8. Genomics 13: 1261-1266 
Foulkes WD, Champbell IG, Stamp GW, Trowsdale J (1993): Loss of heterozygosity and amplification on chromosome $11 \mathrm{q}$ in human ovalian cancer. Br J Cancer 67: 268-273

Gatti R (1991): Localizing the genes for Ataxia-telangiectasia: a human models for inherited cancer susceptibility. Adv Cancer Res 56: 77-104

Gerhard DS, Lawrence E, Wu J, Chua H, Ma N, Bland S, Jones C (1992): Isolation of 1001 new markers from human chromosome 11, excluding the region of $11 \mathrm{p} 13-\mathrm{p} 15.5$, and their sublocalization by a new series of radiation-reduced somatic cell hybrids. Genomics 13: 11331142

Gillet GT, McConville CM, Byrd PJ, Stankovic T, Taylor AM, Hunt DM, West LF, Fox MF, Povey S, Benham F (1993): Irradiation hybrids for human chromosome 11: characterization and use for generating region-specific markers in 11q14-q23. Genomics 15: 332-341

Hampton GM, Penny LA, Baergen RN, Larson A, Brewer C, Liao S, Busby-Earle RMC, Williams AWR, Steel CM, Bird CC, Stanbridge EJ, Evans GA (1994): Loss of heterozygosity in cervical carcinoma: subchromosomal localization of a putative tumor-suppressor gene to chromosome 11a22-a24. Proc Natl Acad Sci USA 91: 6953-6957

Heutink P, Van der May AGL, Sandkuijl LA, Van Gils APG, Bardoel A, Breedvald GJ, Van Vliet M, Van Ommen GJB, Cornelisse CJ, Oostra BA, Weber JL, Devilee P (1992): A gene subject to genomic imprinting and responsible for hereditary paragangliomas maps to chromosome 11q23-qter. Hum Mol Genet 1: 7-10

Hori T, Takahashi E, Tanigami A, Tokino T, Nakamura Y (1992): A high-resolution cytogenetic map of 186 cosmid DNA markers for human chromosome 11. Genomics 13: 129-133

Kapp LN, Painter RB, Yu LC, Van Loon N, Richard CW III, James MR, Cox DR, Murane JP (1992): Cloning of a candidate gene for Ataxia-telangiectasia group D. Am J Hum Genet 51: 45-54

Keldysh PL, Dragani TA, Fleischman EW, Konstantinova LN, Perevoschikov AG, Pierotti MA, Della Porta G, Kopnin BP (1993): 11q deletions in human colorectal carcinomas: cytogenetics and RFLP analysis. Genes Chromosomes Cancer 6: 45-50

Kobayashi H, Episona R III, Fernand AA, Bogy C, Diaz MO, LeBeou MM, Rowly JD (1993): Analyses of deletions of the long arm of chromosome 11 in hematologic malignancies with FISH. Genes Chromosomes Cancer 8: 246-252

Koi M, Shimizu M, Morita H, Yamada H, Oshimura M (1989): Construction of mouse A9 clones containing a single chromosome tagged with neomycin-resistance gene via microcell fusion. Jpn J Cancer Res 80: 413-418

Kugoh H, Nakagawa Y, Mitsuya K, Mita T, Suzuki M, Suzuki N, Uejima H, Yuasa Y, Oshimura M (1995): Isolation and mapping of 186 new DNA markers on human chromosome 1. Genomics $27: 207-210$

Kurimasa A, Nagata Y, Shimizu M, Emi M, Nakamura Y, Oshimura M (1994): A human gene that restores the DNA-repair defect in SCID mice is located on 8p11.1-q11.1. Hum Genet 93:21-26

Leach RJ, Thayer MJ, Chafer AJ, Fournier REK (1989): Physical mapping of human chromosome 17 using fragment-containing microcell hybrids. Genomics 5: 167-176

Ledbetter SA, Nelson DL, Warren ST, Ledbetter DH (1990): Rapid isolation of DNA probes within chromosome regions by interspersed repetitive sequence polymerase chain reaction. Genomics 6: $475-481$

Leonhardt EA, Kapp LN, Young BR, Murane JP (1994): Cloning of a candidate gene for Ataxiatelangiectasia group D. Genomics 19:130-136

Monaco AP, Neve RL, Colleti-Feener C, Bertelson CJ, Kurnit DM, Kunkel LM (1986): Isolation of candidate cDNAs for portions of the Duchenne muscular distrophy gene. Nature 323: 646650

Page DC, Mosher R, Simpson EM, Fisher EMC, Mardon G, Pollac J, McGillivray B, de la Chap-

Jpn J Human Genet 
elle A, Brown LG (1987): The sex-determining region of the human Y chromosome encodes a finger protein. Cell 51: 1091-1104

Rabbits TH (1994): Chromosomal translocations in human cancer. Nature 372: 134-149

Rommens JM, Iannuzzi MC, Kerem BS, Drumm ML, Melmer G, Dean M, Rozmahel R, Cole JL, Kennedy D, Hidaka N, Buchwald M, Riordan JR, Tsui LC, Collins FS (1989): Identification of the cystic fibrosis gene: chromosome walking and jumping. Science 245: 1059-1065

Sanger F, Nicklen S, Coulson AR (1977): DNA sequencing with chain termination inhibitors. Proc Natl Acad Sci USA 74: 5463-5467

Sobel E, Lange E, Jaspers NGJ, Chessa L, Sanal O, Shiloh Y, Taylor AMR, Weemaes CM, Lange K, Gatti RA (1992): Ataxia-telangiectasia: linkage evidence for genetic heterogeneity. Am J Hum Genet 50: 1343-1348

Takahashi E, Hori T, O'Connell P, Leppert M, White R (1990): R-banding and nonisotpoic in situ hybridization: precise localization of the human type II collagen (Co12A1). Hum Genet 86: 14-16

Takahashi E, Yamakawa K, Nakamura Y, Hori T (1992): A high resolution cytogenetic map of human chromosome 3: localization of 291 new cosmid markers by direct R-banding fluorescence in situ hybridization. Genomics 13: 1047-1055

Tamari M, Hamaguchi M, Shimizu M, Oshimura M, Takayama H, Kohno T, Yamaguchi N, Sugimura T, Terada M, Yokota J (1992): Ordering of human chromosome 3p markers by radiation hybrid mapping. Genomics 13: 705-712

Tokino T, Takahashi E, Mori M, Tanigami A, Glaser T, Park JW, Jones C, Hori T, Nakamura Y (1991): Isolation and mapping of 62 new RFLP markers on human chromosome 11. Am J Hum Genet 48 : 258-262

Tomlinson IPM, Gammack AJ, Stickland JE, Mann GJ, Mackie RM, Kefford RF, McGee JO (1993): Loss of heterozygosity in malignant melanoma at loci on chromosome 11 and 17 im plicated in the pathogenesis of other cancers. Genes Chromosomes Cancer 7: 169-172

Ziemin S, McCabe NR, Gill HJ, Episona R III, Patel Y, Harden A, Rubinelli P, Smith SD, LeBeau MM, Rowley JD, Diaz MO (1991): Identification of a gene, MLL, that spans the breakpoint in 11q23 translocations associated with human leukemias. Proc Natl Acad Sci USA 88: 1073510739

Zoghbi HY, McCall AE, LeBorgne-Demarquoy F (1991): Sixty-five radiation hybrids for the short arm of human chromosome 6: their value as a mapping panel and a source for rapid isolation of new probes using repeat element-mediated PCR. Genomics 9: 713-720 